Correspondence: N. Galiè, Institute of Cardiology, University of Bologna, via Massarenti 9, 40138-Bologna, Italy. E-mail: nazzareno.galie@unibo.it

Statement of Interest: Statements of interest for all authors can be found at www.erj.ersjournals.com/site/misc/statements. xhtml

\section{REFERENCES}

1 Galiè N, Hoeper MM, Humbert M, et al. Guidelines for the diagnosis and treatment of pulmonary hypertension. Eur Respir J 2009; 34: 1219-1263.

2 Barst RJ, Rich S, Widlitz A, et al. Clinical efficacy of sitaxsentan, an endothelin-A receptor antagonist, in patients with pulmonary arterial hypertension: open-label pilot study. Chest 2002; 121: $1860-1868$.
3 Hoeper MM, Olsson KM, Schneider A, et al. Severe hepatitis associated with sitaxentan and response to glucocorticoid therapy. Eur Respir J 2009; 33: 1518-1519.

4 Lee W-TN, Kirkham N, Johnson MK, et al. Sitaxentan-related acute liver failure in a patient with pulmonary arterial hypertension. Eur Respir J 2011; 37: 472-474.

5 Lavelle A, Sugrue R, Lawler G, et al. Sitaxentan-induced hepatic failure in two patients with pulmonary arterial hypertension. Eur Respir J 2009; 34: 770-771.

6 European Medicines Agency. Thelin (sitaxentan) to be withdrawn due to cases of unpredictable serious liver injury. www.ema.europa. eu/ema/index.jsp?curl=pages/news_and_events/news/2010/12/ news_detail_001161.jsp\&murl=menus/news_and_events/news_ and_events.jsp\&mid $=$ WC0b01ac058004d5c1\&jsenabled $=$ true Date last updated: December 11, 2010. Date last accessed: December 16, 2010.

DOI: 10.1183/09031936.00194810

\title{
Dyspnoea: a prognostic marker for idiopathic pulmonary fibrosis
}

\section{To the Editors:}

NiSHIYAMA et al. [1] have nicely evaluated the role of dyspnoea in daily life as an independent prognostic marker in idiopathic pulmonary fibrosis (IPF). However, a few patient- and diseaserelated confounding factors should be kept in mind while evaluating this distressing symptom.

IPF is characterised by episodes of rapid deterioration secondary to acute exacerbations or infections [2], which may profoundly increase the severity of breathlessness. This feature has inadvertently not been considered by NisHIYAMA et al. [1] while prognosticating regarding patients with IPF, and has possibly led to inaccurate disease assessment. Serial evaluation of dyspnoea could have solved this issue and strengthened its prognostic role, but was not carried out during the study. In addition, factors such as age, sex and cultural background, disease complications such as pulmonary hypertension, and comorbid conditions such as asthma, anaemia, heart failure and renal failure may significantly alter dyspnoea level and lead to misinterpretation of disease survival. Severity of breathlessness in IPF may also be affected by the nutritional status (muscle mass) and level of daily activity (exercise tolerance) of the subjects, which were not discussed in this study.

Dyspnoea is a purely subjective parameter and can even be altered by a patient's state of mind. More importantly, the patient's perception of dyspnoea (and its grading) may change with involvement of other organ system or the presence of other symptoms about which the patient is more concerned.

Dyspnoea, although the most common symptom of IPF, is at times difficult to interpret. Grading of dyspnoea may provide an important clue regarding disease severity, but should never hinder a clinician from predicting disease outcome using proven objective parameters.
Serial evaluation of dyspnoea may be more appropriate than a single assessment in prognosticating IPF.

\section{Aggarwal* and P.R. Mohapatra ${ }^{\#}$}

*Pulmonary and Critical Care, Fortis Escorts Hospital, Amritsar, and "Dept of Pulmonary Medicine, Government Medical College and Hospital, Sector 32, Chandigarh, India.

Correspondence: D. Aggarwal, Gali No. 5, House No. 11-E, Hukam Singh Road, Amritsar, Punjab, India. E-mail: aggarwaldr@ yahoo.co.in

Statement of Interest: None declared.

\section{REFERENCES}

1 Nishiyama $\mathrm{O}$, Taniguchi $\mathrm{H}$, Kondoh $\mathrm{Y}$, et al. A simple assessment of dyspnoea as a prognostic indicator in idiopathic pulmonary fibrosis. Eur Respir J 2010; 36: 1067-1072.

2 Kim DS, Park JH, Park BK, et al. Acute exacerbation of idiopathic pulmonary fibrosis: frequency and clinical features. Eur Respir J 2006; 27: 143-150.

DOI: $10.1183 / 09031936.00141610$

\section{From the authors:}

We read with genuine interest the correspondence of D. Aggarwal and P.R. Mohapatra, in which they commented on our article demonstrating the relationship between daily dyspnoea and survival in idiopathic pulmonary fibrosis (IPF) [1].

Acute exacerbation of IPF is characterised by acute deterioration of dyspnoea within a few weeks, newly bilateral lung 